\title{
An improved extraction protocol for metagenomic DNA from a soil of the Brazilian Atlantic Rainforest
}

\author{
J.H. Amorim, T.N.S. Macena, G.V. Lacerda-Junior, R.P. Rezende, \\ J.C.T. Dias, M. Brendel and J.C.M. Cascardo \\ Departamento de Ciências Biológicas, Universidade Estadual de Santa Cruz, \\ Ilhéus, BA, Brasil \\ Corresponding author: J.C.M. Cascardo \\ E-mail: cascardo@uesc.br
}

Genet. Mol. Res. 7 (4): 1226-1232 (2008)

Received August 14, 2008

Accepted September 26, 2008

Published November 11, 2008

\begin{abstract}
The need for the prospecting for and identification of new biomolecules is a reality. Molecular techniques allow access to the metabolic potential of microorganisms via the isolation of DNA from environmental samples, i.e., without the application of microbial culture techniques. With its great biological diversity, the Atlantic Rainforest biome has a soil rich in organic matter, some components of which interfere negatively in the reactions necessary for the exploitation of its biotechnological potential. Here, we describe a protocol for the optimization of the treatment of soil samples before DNA extraction. The new methodology gives higher yield and quality of extracted DNA as compared with pre-existing techniques, facilitating the amplification and digestion of environmental DNA, and thus allows optimal exploitation of the genetic potential of the Atlantic Rainforest biome.
\end{abstract}

Key words: Microbial DNA; Lysis; Polymerase chain reaction; Soil; Atlantic Rainforest 


\section{INTRODUCTION}

Microorganisms are the group with the largest distribution on our planet and play an important role in biogeochemical cycles; they are a reservoir of biomolecules with potential use in health care and industrial applications (Robe et al., 2003; Yun et al., 2004). Techniques based on their culture have traditionally been the primary tools applied in studies of microorganisms from different environments (Chandler et al., 1997). However, conventional plate or liquid culture often cannot restore the environmental conditions to which these microorganisms are adapted (Ward et al., 1990; Amann et al., 1995), resulting in failure of their propagation. Thus, these methods do not necessarily provide comprehensive information on the diversity and biotechnological potential of a soil or water sample (for example, see Van Hamme et al., 2003). Molecular methodologies (nucleic acid extraction, polymerase chain reaction (PCR) amplification, cloning and sequencing of DNA) have been optimized and adapted to overcome these limitations, i.e., the isolation of microorganisms is no longer a necessity. These new methodologies allow rapid access to microbial diversity and thus facilitate the discovery of new groups of microorganisms (Amann et al., 1995; Hugenholtz et al., 1998).

The Atlantic Rainforest biome may be a potential source of new biomolecules, especially those with anti-microbial activity (Costa and Siqueira, 2004). However, the soil is not only rich in microorganisms but also in organic matter, especially in humic acids, that denature DNA by binding phenolic groups to amides. This interaction may partially prevent or even totally inhibit enzyme-mediated molecular reactions with extracted DNA (Paul and Clark, 1989; Robe et al., 2003; Whitehouse and Hottel, 2007), whereas the absence of interfering substances in DNA extracts from soil results in good enzymatic reactions, i.e., digestion, amplification and ligation, crucial processes in constructing a metagenomic library. In studies with biotechnological purposes, the method of DNA extraction should provide material in sufficient quantity and quality for further elaboration. Only when these criteria are met can researchers hope to find new genes encoding molecules of interest (Lammle et al., 2007).

There are a large number of published methods for DNA extraction from soil and sediments for studies on autochthonous bacteria (Tsai and Olson, 1991, 1992; Picard et al., 1992; Berthelet et al., 1996; Zhou et al., 1996; Krsek and Wellington, 1999). Here, we report on an improved DNA extraction from soils based on pre-treatment of soil samples before DNA extraction and purification for metagenomic studies.

\section{MATERIAL AND METHODS}

\section{Soil sample}

The Mata Atlântica (Brazilian Atlantic Rainforest) soil sample analyzed in this study was collected at the Caimbi Farm (1451'37’, 3902'04'), Ilhéus, BA. It consisted of a mixture of 20 sub-samples taken from an area of approximately $2 \mathrm{~m}^{2}$ just below the soil surface, to a depth of approximately $10 \mathrm{~cm}$. The sample was sealed in a sterilized glass flask and transported under refrigeration to the Environment Monitoring Laboratory of Universidade Estadual de Santa Cruz, where it was immediately analyzed. Before DNA extraction procedures, the soil sample was sieved (2-mm mesh) and small parts of plants and roots were removed. 


\section{Soil analysis}

The organic and physical-chemical analyses of the soil sample of Mata Atlântica were performed by the Laboratory of Soil and Nutrition of Plants of Embrapa (Cruz das Almas, BA) and are summarized in Table 1.

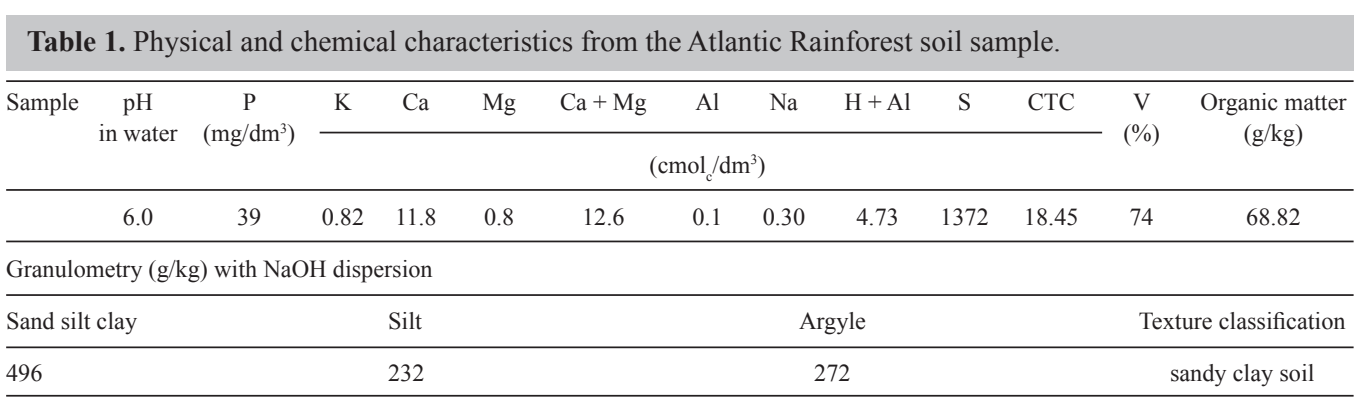

\section{Ex situ DNA extraction methods}

\section{$\operatorname{Method} A$}

A soil sample of $4 \mathrm{~g}$ was introduced into a $250-\mathrm{mL}$ Erlenmeyer flask containing $50 \mathrm{~mL}$ sodium phosphate buffer (and $0.1 \%$ Tween $80, \mathrm{pH} 7$ ). The mixture was incubated under constant agitation overnight at room temperature. The supernatant from this suspension was centrifuged at $5000 \mathrm{rpm}$ for $10 \mathrm{~min}$. The pellet was washed four times with TE buffer 50/50 (50 mM Tris-HCl, $50 \mathrm{mM}$ EDTA, pH 8.1) at $3000 \mathrm{rpm}$ for $3 \mathrm{~min}$. Cells were lysed mechanically by maceration of the liquid nitrogen-frozen pellet. The macerate was transferred to a $15-\mathrm{mL}$ centrifuge tube to which $2 \mathrm{~mL}$ TE buffer 50/50 and an equivalent volume of phenol-chloroform-isoamyl alcohol (25:24:1) were added, and the mixture was centrifuged at $5000 \mathrm{rpm}$ for $10 \mathrm{~min}$. DNA from the collected supernatant was precipitated by adding 0.7 vol. ice-cold isopropanol and 10 vol. $3 \mathrm{M}$ sodium acetate and chilling this mixture for $2 \mathrm{~h}$ at $-20^{\circ} \mathrm{C}$. Another centrifugation at $5000 \mathrm{rpm}$ for 10 min yielded a DNA pellet, which was washed three times with ice-cold $70 \%$ ethanol and once with $95 \%$ ethanol. The DNA was resuspended in $200 \mu \mathrm{L}$ TE buffer 10/0.1 (10 mM Tris-HCl, $0.1 \mathrm{mM}$ EDTA, $\mathrm{pH}$ 8.0) and purified by passing through a Sephadex G200 column (Maciel et al., 2007).

\section{Method B}

The first step of soil sample treatment was as in Method A. The supernatant from this suspension was centrifuged at $5000 \mathrm{rpm}$ for $10 \mathrm{~min}$. Before washing, an equal amount of glass beads was added to the pellet. The pellet was resuspended by 1 min vigorous vortexing and washed for times with TE buffer 50/50 (50 mM Tris-HCl, $50 \mathrm{mM}$ EDTA, 
$\mathrm{pH}$ 8.0) followed by centrifugation at $5000 \mathrm{rpm}$ for $3 \mathrm{~min}$. After each centrifugation, the pellets were resuspended by vortexing for $1 \mathrm{~min}$. After the last wash, $200 \mu \mathrm{L}$ SDS (20\%) was added and the mixture incubated for $20 \mathrm{~min}$ at room temperature. Lysis was performed by thermal shock (in 3 cycles) by exposing the sample for 1 min to liquid nitrogen followed by transfer to boiling water for $4 \mathrm{~min}$. DNA was extracted by the addition of phenol-chloroform-isoamyl alcohol (25:24:1). The mixture was centrifuged at $5000 \mathrm{rpm}$ for $10 \mathrm{~min}$ and the supernatant colleted. To precipitate DNA, 0.7 vol. ice-cold isopropanol and 10 vol. $3 \mathrm{M}$ sodium acetate were added to the supernatant. The reaction mixture was chilled for $2 \mathrm{~h}$ at $-20^{\circ} \mathrm{C}$. DNA was collected by centrifugation at $5000 \mathrm{rpm}$ for $10 \mathrm{~min}$, and the resulting pellet was washed three times with ice-cold $70 \%$ ethanol and once with $95 \%$ ethanol. DNA was resuspended in $200 \mu \mathrm{L}$ TE buffer $10 / 0.1$ (10 mM Tris-HCl, 0.1 mM EDTA, $\mathrm{pH}$ 8.0) and purified by three different procedures: a) Purification 1: Passing through a Sephadex G-200 column; b) Purification 2: Using PVPP (polyvinylpolypyrrolidone) before lysis in combination with a Sephadex G-200 column purification after extraction; c) Purification 3: After extraction and electrophoresis on $0.8 \%$ agarose gel, the DNA band of interest $(38 \mathrm{~kb})$ was cut out and the DNA was released by passing through a GFX column (Amersham Biosciences).

\section{Comparison of DNA yields}

DNA extracted by Methods A and B from identical soil samples was quantified by spectrophotometric analysis with Genequant (GE Healthcare). Visual comparison was under UV light after electrophoresis of $10 \mu \mathrm{L}$ DNA solution on $0.8 \%$ agarose gel with $1 \mathrm{X}$ TE buffer and ethidium bromide staining.

\section{PCR of DNA extracted by the Method B}

After the purification steps, DNA samples were submitted to PCR amplification. Samples from purifications \#1 and \#2 were diluted 100-fold while DNA from purification \#3 was used undiluted. A region from the $16 \mathrm{~S}$ rRNA gene was amplified using primers 27f[5'- AgAgTTTgATCMTggCTCAg- 3'] and 1525r- [5'- AAggAggTgWTCCARCC- 3'] in a PTC200 thermocycler (Eppendorf). Each $25 \mu \mathrm{L}$ PCR mixture contained 10 ng environmental DNA (eDNA), 1X PCR buffer, $200 \mu \mathrm{M}$ of each deoxyribonucleoside triphosphate, $0.2 \mu \mathrm{M}$ sense and anti-sense primers, $3.7 \mathrm{mM} \mathrm{MgCl}, 0.4 \mathrm{mg} / \mathrm{mL}$ BSA and $3 \mathrm{U}$ Taq DNA polymerase $\left(\mathrm{PROMEGA}^{\circledR}\right)$. The amplification cycle consisted of an initial denaturation step of $5 \mathrm{~min}$ at $94^{\circ} \mathrm{C}$, followed by 34 cycles of $1 \mathrm{~min}$ at $94^{\circ} \mathrm{C}, 1 \mathrm{~min}$ at $59^{\circ} \mathrm{C}$ and $2 \mathrm{~min}$ at $72^{\circ} \mathrm{C}$, with a final extension step for $10 \mathrm{~min}$ at $72^{\circ} \mathrm{C}$. For visualizing PCR products, $5 \mu \mathrm{L}$ of the suspension was submitted to electrophoresis on $1 \%$ agarose gels in $1 \mathrm{X}$ TBE buffer, stained with ethidium bromide, and placed under UV light.

\section{Digestion by EcoRI and BamHI}

DNA extracted by the Method B and submitted to purification procedures \#1 and \#2 was compared with the eDNA extracted by the Method A for susceptibility to BamHI and EcoRI restriction (110 ng eDNA exposed to 10 units of restriction enzyme). 


\section{RESULTS AND DISCUSSION}

Amplification of eDNA by PCR was used to determine its quality. Among the three purification methods that were applied to soil-extracted DNA, protocols \#1 and \#2 yielded eDNA ready for efficient PCR amplification (Figure 1). Purification procedure \#3, even though giving an acceptable level of eDNA, was not suitable for PCR amplification. Since PCR involves successive enzymatic reactions (Riesenfeld et al., 2004) and since DNA polymerase requires contamination-free sites, it appears that purification procedure \#3 was not efficient (Figure 1, lanes 6 and 7). Probably not all contaminating (DNA-adhering) substances were removed and this could have led to inhibition of the initial PCR product on the original eDNA (Kozdroj and van Elsas, 2001; Robe et al., 2003; Roh et al., 2006).

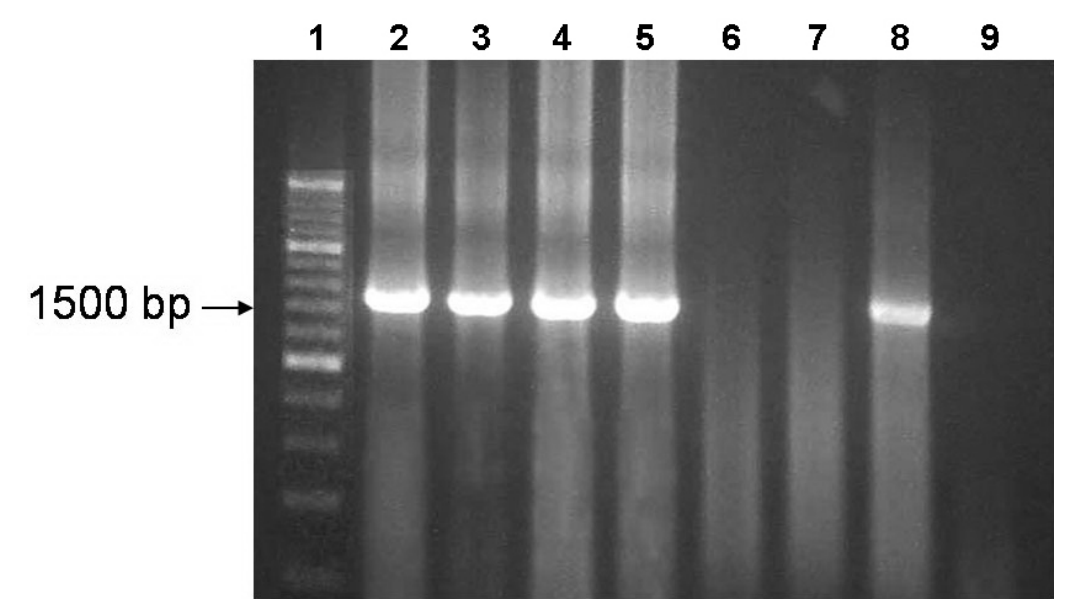

Figure 1. Polymerase chain reaction (PCR) amplification of $16 \mathrm{~S}$ rDNA extracted by the Method B and purified by 3 different procedures. Lane $1=$ molecular weight markers $(200-3000 \mathrm{bp})$; lane $2=$ PCR of $1 \mu \mathrm{L}$ DNA, procedure 1 ; lane $3=$ PCR of $3 \mu \mathrm{L}$ DNA, procedure 1 ; lane $4=$ PCR of $1 \mu \mathrm{L} \mathrm{DNA}$, procedure 2 ; lane $5=$ PCR of $3 \mu \mathrm{L}$ DNA, procedure 2; lane $6=\mathrm{PCR}$ of $1 \mu \mathrm{L}$ DNA, procedure 3 ; lane $7=\mathrm{PCR}$ of $3 \mu \mathrm{L} \mathrm{DNA}$, procedure 3 ; lanes 8 and $9=$ positive and negative control.

\section{DNA yield, quality and digestion by EcoRI and BamHI}

Spectrophotometer readings showed that DNA extraction by the Method A yielded 310 $\mathrm{ng} / \mu \mathrm{L}$, whereas by the Method B yielded $1000 \mathrm{ng} / \mu \mathrm{L}$. The method B yielded $50 \mu \mathrm{g}$ DNA/g of soil sample and therefore proved to be more efficient than the extraction method described by Roh et al. (2006), which resulted in a yield of $8.3 \mu \mathrm{g} D N A / g$ of soil sample. The difference in eDNA yield from the Method B compared to that of the Method A was also observed visually by band analysis after electrophoresis of extracts (Figure 2). The main differences between the two methods were the addition of glass beads (after removal of soil) and lysis by thermal shock in the Method B versus maceration in the Method A. Lysis by thermal shock had already been reported to contribute to a higher DNA yield in soil sample extraction (Dubey et al., 2006). 


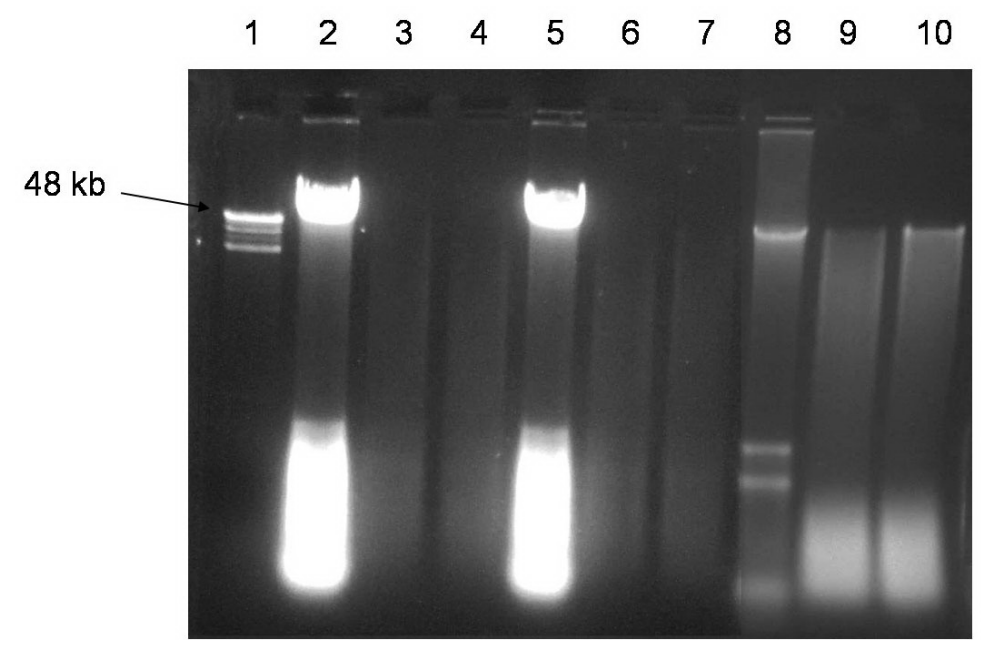

Figure 2. Digestion by restriction enzymes EcoRI and BamHI of DNA extracted from soil via Methods A and B. Lane 1 = molecular weight marker 20-40 kb; lane $2=$ Method B, procedure 1, undigested; lane $3=$ Method B, procedure 1, Bam HI; lane $4=$ Method B, procedure 2, Bam HI; lane $5=$ Method B, procedure 2, undigested; lane 6 $=$ Method B, procedure 1, EcoRI; lane $7=$ Method B, procedure 2, EcoRI; lane 8 = Method A, undigested; lane 9 $=$ Method A, EcoRI; lane $10=$ Method A, BamHI.

DNA extracted by the Method B had a UV absorption ratio $260_{\mathrm{nm}} / 230_{\mathrm{nm}}$ of 1.9 , while this ratio was 1.25 for DNA extracted via the Method A. This suggested that DNA extracted via the Method B gave a DNA free from adhering humic acids (Roh et al., 2006). The UV absorption ratio $260_{\mathrm{nm}} / 280_{\mathrm{nm}}$ of DNA extracted by Methods A and B was between 1.6 and 1.7 showing that the two eDNAs were relatively free of protein contamination. These differences in purity levels between the DNA samples extracted by Methods A or B may explain the observed differences in efficiency of their digestion by the restriction enzymes EcoRI and BamHI, where the DNA extracted by the Method B and purified by procedures \#1 or \#2 was easily digested, but that extracted by the Method A was only partially digested by either enzyme (Figure 2).

\section{CONCLUSION}

An optimized extraction and purification protocol for DNA from a soil sample from the Atlantic Rainforest yielded eDNA in good quantity and high quality, which was suitable for library construction. The method B (thermal lysis followed by DNA purification) proved to be superior to the Method A (sample maceration and DNA purification). UV absorption profiles showed that this eDNA was relatively free of adhering soil components such as humic acids and also free of protein contamination. In addition, two of three DNA purification procedures (\#1 and \#2) of eDNA extracted by the Method B yielded DNA that could be readily amplified by PCR and was thus suitable for phylogenetic studies. Due to the low level of contamination, DNA extracted by the Method B was readily digested by restriction enzymes EcoRI and BamHI. This DNA can be successfully employed for metagenomic studies of Atlantic Rainforest soil. 


\section{ACKNOWLEDGMENTS}

J.H. Amorim and T.N.S. Macena are recipients of graduate FAPESB fellowships and G.V. Lacerda-Junior is the recipient of a CNPq undergraduate fellowship. M. Brendel is a Visiting Professor supported by FAPESB. Research supported by CNPq (\#506356/2004-3).

\section{REFERENCES}

Amann RI, Ludwig W and Schleifer KH (1995). Phylogenetic identification and in situ detection of individual microbial cells without cultivation. Microbiol. Rev. 59: 143-169.

Berthelet M, Whyte LG and Greer CW (1996). Rapid, direct extraction of DNA from soils for PCR analysis using polyvinylpolypyrrolidone spin columns. FEMS Microbiol. Lett. 138: 17- 22.

Chandler DP, Fredrickson JK and Brockman FG (1997). Effect of PCR template concentration on the composition and distribution of total community 16S rDNA clone libraries. Mol. Ecol. 6: 475-482.

Costa JL and Siqueira ER (2004). Análise de DNA dos Solos e Atividade Enzimática como Bioindicadores de Diversidade Microbiana em Sistemas de Restauração Florestal da Mata Atlântica. In: II Seminário de Pesquisa FAP-SE. EMBRAPA, Aracaju.

Dubey SK, Tripathi AK and Upadhyay SN (2006). Exploration of soil bacterial communities for their potential as bioresource. Bioresour. Technol. 97: 2217-2224.

Hugenholtz P, Goebel BM and Pace NR (1998). Impact of culture-independent studies on the emerging phylogenetic view of bacterial diversity. J. Bacteriol. 180: 4765-4774.

Kozdroj J and van Elsas JD (2001). Structural diversity of microbial communities in arable soils of a heavily industrialised area determined by PCR-DGGE fingerprinting and FAME profiling. Appl. Soil Ecol. 17: 31-42.

Krsek M and Wellington EM (1999). Comparison of different methods for the isolation and purification of total community DNA from soil. J. Microbiol. Methods 39: 1-16.

Lammle K, Zipper H, Breuer M, Hauer B, et al. (2007). Identification of novel enzymes with different hydrolytic activities by metagenome expression cloning. J. Biotechnol. 127: 575-592.

Maciel BM, Dias JC, Dos Santos AC, Filho RC, et al. (2007). Microbial surfactant activities from a petrochemical landfarm in a humid tropical region of Brazil. Can. J. Microbiol. 53: 937-943.

Paul EA and Clark FE (1989). Soil Microbiology and Biochemistry. Academic Press, New York.

Picard C, Ponsonnet C, Paget E, Nesme X, et al. (1992). Detection and enumeration of bacteria in soil by direct DNA extraction and polymerase chain reaction. Appl. Environ. Microbiol. 58: 2717-2722.

Riesenfeld CS, Schloss PD and Handelsman J (2004). Metagenomics: genomic analysis of microbial communities. Annu. Rev. Genet. 38: 525-552.

Robe P, Nalin R, Capellano C, Vogel TM, et al. (2003). Extraction of DNA from soil. Eur. J. Soil Biol. 39: 183-190.

Roh C, Villatte F, Kim BG and Schmid RD (2006). Comparative study of methods for extraction and purification of environmental DNA from soil and sludge samples. Appl. Biochem. Biotechnol. 134: 97-112.

Tsai Y-L and Olson BH (1991). Rapid method for direct extraction of DNA from soil and sediments. Appl. Environ. Microbiol. 57: 1070-1074.

Tsai Y-L and Olson BH (1992). Rapid method for separation of bacterial DNA from humic substances in sediments for polymerase chain reaction. Appl. Environ. Microbiol. 58: 2292-2295.

Van Hamme JD, Singh A and Ward OP (2003). Recent advances in petroleum microbiology. Microbiol. Mol. Biol. Rev. 67: 503-549.

Ward DM, Weller R and Bateson MM (1990). 16S rRNA sequences reveal numerous uncultured microorganisms in a natural community. Nature 345: 63-65.

Whitehouse CA and Hottel HE (2007). Comparison of five commercial DNA extraction kits for the recovery of Francisella tularensis DNA from spiked soil samples. Mol. Cell Probes 21: 92-96.

Yun J, Kang S, Park S, Yoon H, et al. (2004). Characterization of a novel amylolytic enzyme encoded by a gene from a soil-derived metagenomic library. Appl. Environ. Microbiol. 70: 7229-7235.

Zhou J, Bruns MA and Tiedje JM (1996). DNA recovery from soils of diverse composition. Appl. Environ. Microbiol. 62: 316-322. 